\title{
Air Quality in a Cleaner Energy World
}

\author{
Donald J. Wuebbles ${ }^{1,2} \cdot$ Swarnali Sanyal $^{1}$
}

Published online: 12 July 2015

(C) Springer International Publishing AG (outside the USA) 2015

\begin{abstract}
Two major environmental issues, air quality and climate change, are interlinked because of their large dependence on atmospheric emissions from human activities, especially from the burning of fossil fuels. Emission of air pollutants and heat trapping gases have greatly increased over the last five decades from our dependence throughout the world on conventional fossil fuel sources in production of electricity and in transportation systems, resulting in significant environmental issues with air quality and climate change throughout our planet. Future emissions of pollutants will depend on the choices made about our use of energy and transportation. The purpose of this study is to examine for now and into the future the relationship between energy production, the associated use of fossil fuels, and resulting effects on air pollution. In the process, we examine a clean energy future, imagined in this case for 2050, and then consider the resulting potential effects on air quality.
\end{abstract}

Keywords Energy $\cdot$ Air quality $\cdot$ Ozone $\cdot$ Particles

\section{Introduction}

One of the biggest challenges that the world faces today is providing clean and sustainable energy to future generations.

This article is part of the Topical Collection on Air Pollution

Donald J. Wuebbles

wuebbles@illinois.edu

Swarnali Sanyal

ssanyal3@illinois.edu

1 Department of Atmospheric Sciences, University of Illinois, 105 South Gregory Street, Urbana, IL 61801, USA

2 National Science Foundation, 4201 Wilson Blvd, Arlington, VA 22230, USA
With a growing population and increasing economic development throughout the world, there is an ever-increasing need and stress on energy production. Every sector of human life is now energy dependent, be it for transportation, or electricity demands or heating and cooling system. From 1971 to 2012, the world's total energy supply increased from 6106 Mtoes (megatons of oil equivalent energy) to 13,371 Mtoes [1・•], while the total consumption of energy almost doubled, from 4672 to 8979 Mtoes. Meanwhile, the world's consumption of electricity almost quadrupled during this same period, from $6129 \mathrm{TWh}$ (terawatt hours) to $22,668 \mathrm{TWh}$. In $2012,81.7 \%$ of the global total primary energy supply, $67.9 \%$ of global electricity generation, and $78.3 \%$ of global total final consumption were met by fossil fuels. With the world population expected to continue to rise from about 7 billion today (2015) to about 9.6 billion in 2050 , the demand for energy will continue to increase. The corresponding increase in energy and transportation needs and their major dependence on fossil fuels create several major problems that need to be dealt with over the coming decades, for example, the effects of fossil fuel emissions on climate and on air quality, and an uneven distribution of fossil fuels and other energy sources leading to a growing dependence in some countries on others for energy availability $[1 \bullet \bullet]$.

Many of the pertinent environmental issues today, such as local and regional air pollution, acid precipitation (also called acid rain), and global climate change (or global warming as it gets called by the media), can be traced primarily to emissions from the use of fossil fuels for different energy and transportation sectors. Air quality is most strongly affected by some of the short-lived species like carbon monoxide (CO), different oxides of nitrogen $\left(\mathrm{NO}+\mathrm{NO}_{2}=\mathrm{NO} x\right)$, sulfur dioxide $\left(\mathrm{SO}_{2}\right)$, ozone $\left(\mathrm{O}_{3}\right)$, volatile organic compounds (VOCs), and various atmospheric particles (also called aerosols). The particles of most concern are those that can lodge deeply into the lungs; these are primarily the particles of less than $2.5 \mu \mathrm{m}$ in diameter 
(called PM2.5) that are primarily produced from gases like $\mathrm{SO}_{2}$, but also includes black carbon (soot) and other very fine particles. Some of the pollutants like NOx and VOCs are especially important for forming ozone, a key component of urban smog, whereas $\mathrm{SO}_{2}, \mathrm{NO} x$ and other gases can produce particles that also lead to environmental concerns from acid rain. A variety of gases and particles, especially the long-lived gases like carbon dioxide $\left(\mathrm{CO}_{2}\right)$, methane $\left(\mathrm{CH}_{4}\right)$, nitrous oxide $\left(\mathrm{N}_{2} \mathrm{O}\right)$, and various chlorofluorocarbons ( $\left.\mathrm{CFCs}\right)$ and other halocarbons, are of special concern to the changes occurring in the Earth's climate system. The CFCs and other halocarbons have also been the primary sources of observed decreases in stratospheric ozone that are now in the process of being controlled through the international Montreal Protocol to Protect the Stratospheric Ozone Layer.

Some of the atmospheric pollutants are directly emitted into the atmosphere from various anthropogenic and natural activities, and can have direct effects on the environment, while others are formed from secondary reactions (and from other processes, e.g., the nucleation of aerosols) in the atmosphere. Emissions from vehicles are the primary source of $\mathrm{CO}_{2}, \mathrm{CO}$, NOx, and human-related VOCs, while electric utilities and industry are important sources for $\mathrm{CO}_{2}, \mathrm{CH}_{4}, \mathrm{NO}$, VOCs, and $\mathrm{SO}_{2}$. VOCs are not only emitted from the sources mentioned above, they are also emitted from natural sources. $\mathrm{O}_{3}$ is a secondary pollutant formed in the atmosphere from photochemical reactions, especially between $\mathrm{NO} x$ and VOCs. The local and regional air pollutants like ozone and the particles (PM2.5) can significantly affect human health through the cardio-vascular and pulmonary system, causing shortness of breath, asthma, other issues - these effects are particularly harmful for children and the elderly.

The major sources of PM2.5 are biomass burning and fossil fuel combustion. Almost all of the aerosols in the atmosphere have heterogeneous composition and are composed of inorganic and organic components. Ammonium nitrate, sulfate, and chloride mostly make up the inorganic fraction. The particles are formed due to the reaction between $\mathrm{NH}^{+4}$ (mostly resulting from anthropogenic activities like use of fertilizer or from animal husbandry $[2,3]$ ) and $\mathrm{SO}^{-4}$ (from oxidation of $\mathrm{SO}_{2}$ mostly emitted from coal-burning power plants [4]), $\mathrm{NO}^{-3}$ (formed from oxidation of NOx emitted from fossil fuel combustion and biomass burning [5]), or with $\mathrm{Cl}^{-}$(from sea spray or from hydrochloric acid emitted from incinerators or power plants [6]). The second major component making up the aerosols is the carbonaceous fraction that includes black carbon aerosols $(\mathrm{BC})$ and organic aerosols $(\mathrm{OA})$ that contain carbon along with hydrogen and oxygen. Organic aerosols have both natural biogenic sources and human-related emissions like biomass burning and meat cooking [7-9]). OA can also form in the atmosphere due to complex chemical reaction involving VOCs and subsequent gas to particle conversion [10], thus forming secondary organic aerosol (SOA). Organic carbon (OC) is the fraction of carbon in organic aerosol excluding the associated hydrogen and oxygen [11, 12]. Black carbon or soot is the other carbonaceous fraction of aerosol and is formed during combustion processes.

According to estimates made by the World Health Association (WHO), about 7 million people die each year as a result of their exposure to air pollution (http://www.who.int/ mediacentre/news/releases/2014/air-pollution/en/). This estimate is more than twice larger than prior estimates because of stronger links to heart disease and strokes. This corresponds to roughly one in 8 of total global deaths per year. Over half of these, about 3.7 million (in 2012) are related to outdoor air pollution. WHO also states that this confirms that air pollution is now the world's largest single environmental health risk. Countries with the highest risks include China, with over 1.2 million deaths per year from outdoor air pollution, mostly related to exposure to particulate matter and India, with over 600,000 deaths per year $[1 \bullet \bullet]$.

Ambient particulate matter pollution remains in the top 10 risk factors associated with Disability Associated Life Years in the USA but declined by $35 \%$ since 1990 (US Burden of Disease Collaborators, 2013) and is one of the major air pollutants [13], causing negative effects on human health [14, 15], impairing visibility [16], and affecting climate [17]. Recent studies still suggest that there are about 200,000 outdoor air pollution related premature deaths in the USA each year related to PM2.5 and another 10,000 due to changes in ambient levels of ozone, with the primary source of emissions coming from combustion of fossil fuels [18].

The purpose of this study is to examine the relationship between energy production, and the associated use of fossil fuels, and resulting effects on air pollution. In the process, we examine a clean energy future imagined in this case for 2050 and then to consider the resulting effects on air quality. The next section looks into the current energy use portfolio and its impact on air quality in the USA and worldwide. This is followed with a discussion of projections of future energy needs and scenarios for the corresponding emissions of air pollutants. Finally, we examine scenarios for a clean energy future and the resulting implications on future emissions of air pollutants.

\section{Current Energy and Resulting Pollutant Emissions and Concentrations}

Figure 1 shows a conceptual diagram of key components in the global energy system. Shown in Fig. 1 are conventional sources of energy from fossil fuels, e.g., from coal, natural gas, and oil, and alternate sources of energy such as biomass burning, nuclear power, and renewable sources (which includes a number of different possibilities including wind, 
Fig. 1 Key components of the global energy system. The red arrows indicate the pathways for use of different energy sources in the different sectors. The blue arrows indicate the pathway for generation of air pollutant emissions

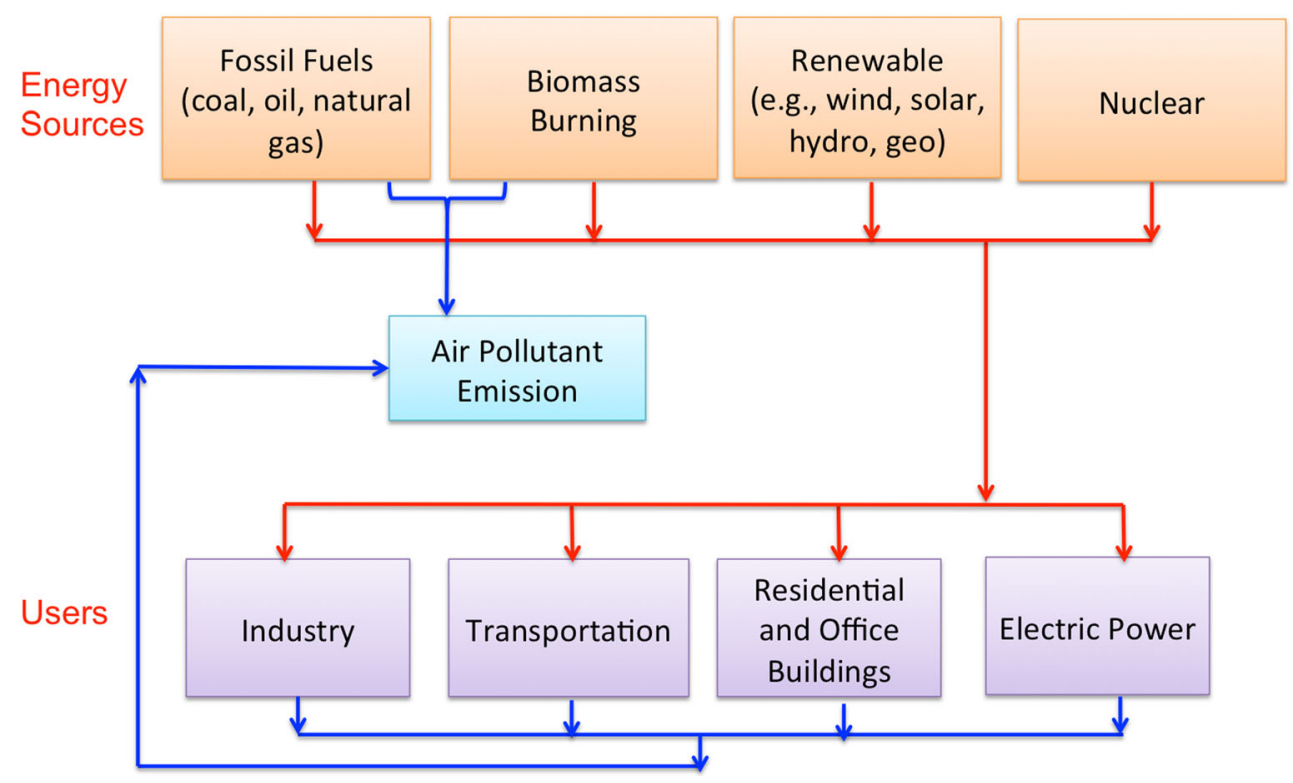

solar, hydroelectricity, and geothermal). The resulting energy produced is used in a variety of different sectors including industry, homes, office buildings, and transportation (which includes road vehicles, trains, ships, and others). A major factor in this system is the generation of pollutants, especially emissions that affect air quality and climate change, plus other environmental concerns listed in Table 1. The use of fossil fuels is by far the largest source of air pollutants but biomass burning also contributes to the production of $\mathrm{CO}, \mathrm{NO} x$, VOCs, and some other pollutants. Direct use of fossil fuels and biomass by end users, e.g., in transportation systems or in heating homes, also contribute significantly to pollutant production. The pathway of air pollutant emissions is shown using blue arrows.

Electricity generation accounted for $38 \%$ of global primary energy use in 2010 making it the single largest element of primary demand $[19 \bullet \bullet]$. The global electricity supply sector accounts for about $80 \%$ of the total human-related $\mathrm{CO}_{2}$ emissions in 2010 [20]. Energy production, industry, transportation, and buildings account for $47,30,11$, and $3 \%$ rise, respectively, in GHG emission from 2000 to 2010 [21 ••]. Coalfired power plants have been the primary source of pollutant emissions from the power production sector [22••].

About $40 \%$ of US energy is used in the private, commercial, and institutional activities associated with residential and commercial buildings while roughly $30 \%$ is used in industries and another $30 \%$ in transport of goods and passengers [23]. Transportation accounts for $29 \%$ of total global energy consumption $[1 \bullet \bullet$. At present the transportation sector depends primarily on fossil fuel burning, especially oil consumption through gasoline and diesel fuel. According to the U.S. Environmental Protection Agency (EPA), mobile sources, including both onroad sources and non-road sources are major emitters of pollutants in the U.S. Mobile sources are also one the major contributor to air toxics. Gasoline is one of the major contributors of benzene emission. EPA identified that emissions from vehicles contributed to about 21 of the 188 identified hazardous air pollutants.

Figure 2 shows the emissions of different air pollutants for the USA and the world from different energy sectors, including stationary sources (like fuel combustion in electrical utilities and industries), industries, and transportation (including both highway and non-highway vehicles). In the USA, fossil fuels account for $90 \%$ of all energy production and use [24] and contributed to about 87,3 , and $14 \%$ of $\mathrm{SO}_{2}, \mathrm{VOC}$, and PM2.5 emissions, respectively (adapted from the National Emission Inventory of air pollutants in 2010 by EPA, http:// www.epa.gov/ttnchie1/trends/). States with larger areas, larger populations, and more intensive energy industries typically use more energy (EAP, 2012). The transportation sector also contributes greatly to pollutant emissions, about 53, 23, 57, and $6 \%$ respectively to total $\mathrm{CO}, \mathrm{VOC}, \mathrm{NO} x$, and PM2.5 emissions in the USA. The US damages from the transportation sector are about $\$ 56$ million in health and from coal and natural gas are $\$ 62$ billion and $\$ 740$ million, respectively, due to emissions of criteria pollutants, not including the effects on climate [25]. The emission data for the world was obtained from the IPCC RCP4.5 scenario, which is described in a later section (http://tntcat.iiasa.ac. at: $8787 / \mathrm{RcpDb} / \mathrm{dsd}$ ? Action $=$ htmlpage $\&$ page $=$ compare) [26-31]. Fossil fuel contributed about 50 and $13 \%$, respectively, to $\mathrm{SO}_{2}$ and $\mathrm{VOC}$ emissions, and stationary combustion sources in total contributed about 78 and $16 \%$, respectively, of $\mathrm{SO}_{2}$ and $\mathrm{VOC}$ emissions, while transportation (including surface transportation, international shipping, and aviation) contributed about 21,19 , and $45 \%$ to CO, VOC, and NOx emissions, respectively. 
Table 1 Different air pollutants resulting from human activities that affect important environmental issues

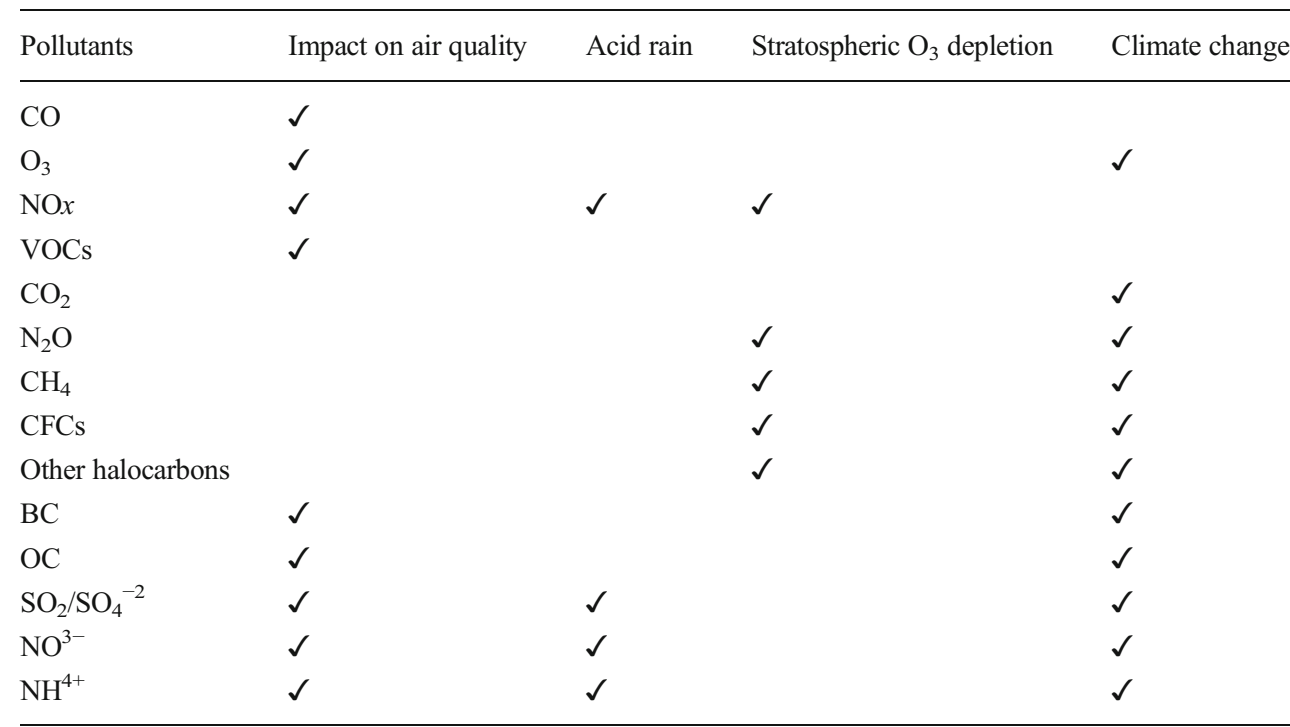

Check marks show the different cases where the pollutants contribute to various environmental issues. VOCs and CFCs include emissions of a number of different gases. Ozone is produced in the atmosphere, and is a very important component of local air pollution, but it is not directly emitted by human activities. Some pollutants, like those of mercury $(\mathrm{Hg})$ from coal burning, are not included in this list because they primarily affect the environment by other means

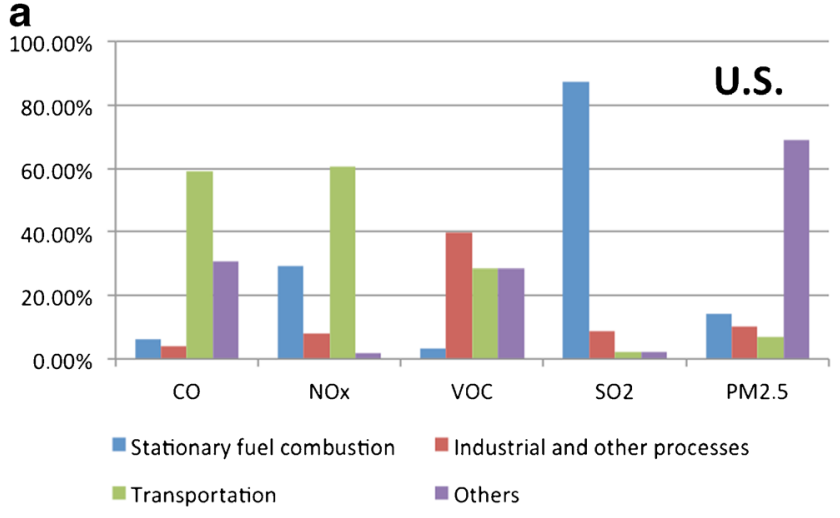

b

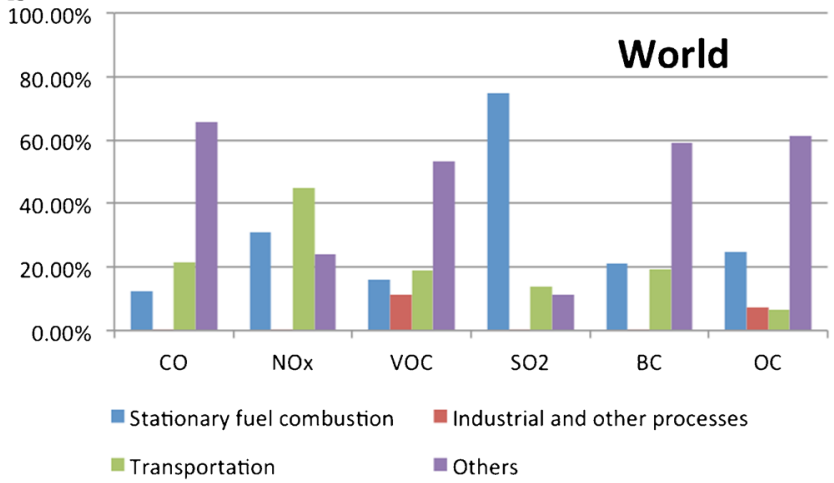

Fig. 2 Emissions from stationary fuel combustion, industrial processes and transportation sector in 2010 in the USA (adapted from data in the National Emission Inventory for 2010 by EPA) and the World (adapted from emission data from RCP4.5 scenario) in panels a and panel $\mathbf{b}$, respectively
According to EPA, large reductions in pollution emissions in the USA occurred from 2001 to 2010 , including a $\mathrm{NO}_{2}$ decrease by $33 \%$, CO decrease by $52 \%, \mathrm{SO}_{2}$ decrease by $50 \%$, ground level $\mathrm{O}_{3}$ decrease by $13 \%$, and PM 2.5 decrease by $24 \%$. This resulted primarily from a shift to cleaner technologies (control measures applied on vehicular emissions and on industries like chemical plants, dry cleaners, coke ovens, and incinerators). Despite this reduction, millions of people in the USA still live in counties that exceed one or more of the National Ambient Air Quality Standards (NAAQS) [32]. A similar trend is seen overall in the world, with emissions of pollutants in the Asian countries actually increasing as they continue to build their economies. Without major control measures, the world's energy demand will likely continue to increase, with estimates of about $22 \%$ [33] from 2010 to 2035. Existing control measures are definitely not sufficient to reduce air pollution enough to greatly reduce health concerns. Worldwide, as population continues to increase and economies develop, so does the demand on the energy sector, increasing emissions from fuel combustion, industry, and transportation, leading to further concerns about pollutant emissions and degrading air quality.

\section{Future Projection of Air Quality}

Climate change is one of the most important issues of our time $[21 \bullet \bullet, 34]$. The science is clear that climate change is not just a problem for the future, it is happening now across the world, and we are already being affected by changing trends in 
certain types of severe weather and by the rising sea level. Analyses of past changes in climate show that the recent changes are occurring over 10 times faster than past natural changes. The scientific evidence also clearly points to the emissions from the burning of fossil fuels used for transportation and energy as being the primary cause of the changes in climate observed over at least the last five decades.

The changing climate is already affecting humanity and our economies in many ways. These effects will increase as the climate continues to change, and the effects are expected to increase dramatically over the coming decades [24, 34]. Large reductions in global emissions of the heat-trapping gases could avoid some of the damaging impacts of climate change. Just as importantly, countries and their local communities that adapt and prepare for the range of climate change impacts can prevent needless harm.

Air quality and climate change are interlinked in a variety of ways. Emissions of both long-lived pollutants like $\mathrm{CO}_{2}$ and methane, and short-lived climate forcing pollutants like black carbon and $\mathrm{SO}_{2}$ need to be addressed if we want to really mitigate or slow down the amount of future climate change. At the same time, reducing emissions that affect climate would also reduce the concerns about air quality. Coordinated action on both climate change and air quality is necessary $[35-41,42 \cdot \bullet]$.

Climate change will continue-global emissions and concentrations of $\mathrm{CO}_{2}$ and other heat-trapping gases continue to rise. Choices made now and in the next few decades about emissions from fossil fuel use and land use change will determine the amount of additional future warming over this century and beyond. How much climate will change depends on (1) human activities and resulting emissions and (2) how sensitive the climate is to those changes (that is, the response of global temperature to a change in radiative forcing caused by human emissions). Uncertainties in how the economy will evolve, what types of energy will be used, and how our cities, buildings, and vehicles will evolve all limit the ability to make accurate projections of future changes in climate. As a result, scenarios-plausible projections of what might happenhave been developed for a range of different assumptions. These scenarios describe possible futures in terms of population, economic development, energy sources, technology, lifestyle choices, heat-trapping gas emissions, atmospheric levels of carbon dioxide, and/or global temperature change.

On the global scale, climate model simulations show consistent projections of future conditions under a range of emission scenarios [24, 34]. The most commonly used sets of scenarios used in these studies are those from the 2000 IPCC Special Report on Emission Scenarios (SRES) [43] and the 2010 Representative Concentration Pathways (RCPs) [44]. The latter were used in the latest international climate assessment [24]. Comparing carbon dioxide concentrations and global temperature change between the SRES and RCP scenarios, the high SRES A1FI scenario is similar to RCP8.5, the middle scenario SRES A1B to RCP6.0, and the low scenario SRES B1 to RCP4.5. The RCP2.6 scenario is much lower than any SRES scenario because it includes the option of using policies to significantly reduce emissions and also requires net negative carbon dioxide emissions in the later decades of this century where $\mathrm{CO}_{2}$ would need to be removed from the atmosphere, while the SRES scenarios do not attempt such a policy requirement [34]. The high scenarios assume continued heavy use of fossil fuels while the lower scenarios assume different rates of movement towards alternative energy sources.

As has been shown in a number of studies [39, 45-52], the warmer summer climates throughout much of the world will lead to more concerns about ozone production. Major air pollutants like $\mathrm{O}_{3}$ and PM2.5 are dependent on many meteorological parameters making it imperative to understand the relationship between air quality and meteorology [53]. Various studies [45, 46, 54] have also shown that the effects of climate change itself (e.g., changes in temperature) on air quality are small relative to the effects of future emissions of NOx and VOCs on air quality. Recent studies conclude that $\mathrm{O}_{3}$ and PM2.5 concentrations would decrease in the continental USA in the future under lower climate change scenarios like B1 or RCP4.5 [45, 46, 49, 53, 55, 56]. But for high emission scenarios like RCP8.5, ozone concentrations would increase due to the continuing dependence on fossil fuels and also high methane emissions assumed [52]. In the middling A1B scenario, which has rapid economic growth and balanced energy growth from both fossil fuel and alternative sources of energy, NOx emissions from fossil fuels are projected to decrease by $40 \%$ in the USA but are likely to increase by $90 \%$ globally [49]. In all cases, projected mean surface ozone and aerosol concentrations were more sensitive to the projected anthropogenic emissions than they were to the changes in climate.

These and other studies have shown that policies to limit future climate changes by encouraging alterative energy sources and a reduction in emissions from burning fossil fuels would also result in a reduction in emissions affecting ozone and PM2.5. Also, policies to protect air quality tend to lead to more efficient energy production and transportation systems that reduce the emissions of carbon dioxide, the gas of most concern to climate change.

The general conclusions from existing studies is that the high scenarios like A1FI and RCP8.5 result in much larger pollutant emissions and near surface ozone and PM2.5 concentrations than the middle emission scenarios like A1B and RCP6.0 and the low emission scenarios like B1 and RCP4.5 [38, 45, 46, 57-60]

Figure 3 shows the worldwide anthropogenic emission various gases and aerosols for the different RCP scenarios (adapted from IPCC 2014 [21••]). For the RCP2.6 scenario, all pollutant emissions decrease remarkably except for $\mathrm{NO} x$ 
a

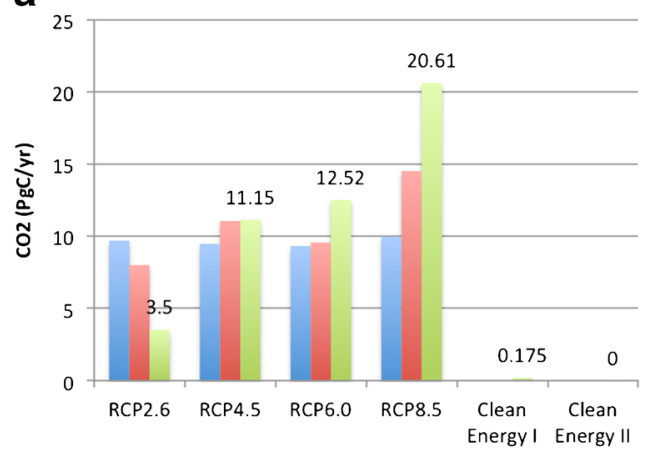

C

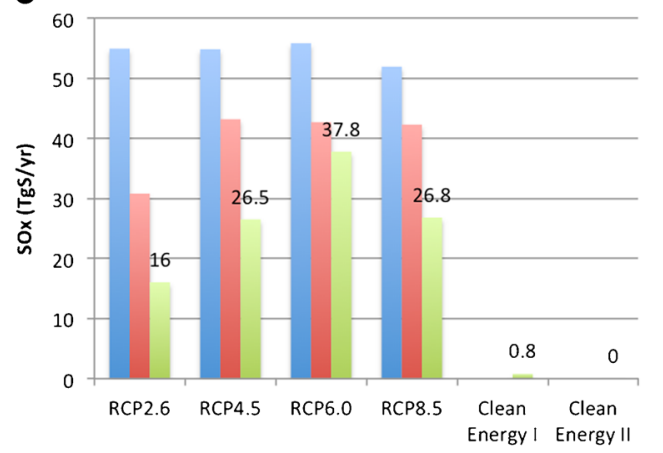

e

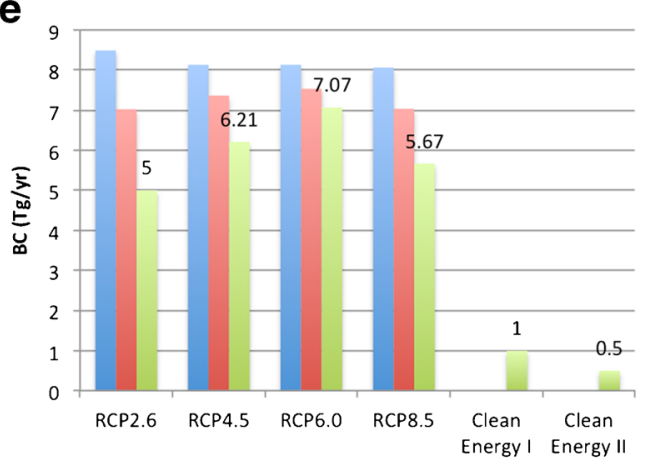

Fig. 3 Global human-related emissions for $\mathrm{CO}_{2}$ (a) and short-lived gases (b to d) and aerosols (e and $\mathbf{f}$ ) under the Representative Concentration Pathway scenarios from IPCC, 2013, for 2010 and projections to 2030 and 2050. Finally, we show estimated emissions Clean Energy Scenario I

emissions. $\mathrm{CO}_{2}$ emissions increase from 2010 to 2050 for all the other three scenarios. CO, VOCs, $\mathrm{SO} x$ (which is mostly $\mathrm{SO}_{2}$ but also includes some other minor sulfur gases), and $\mathrm{BC}$ have lower emission in 2050 compared to 2010 , but in some cases, they show a slight increase in 2030. It is well recognized that the RCP scenarios are not likely representative of future $\mathrm{BC}$ and $\mathrm{OC}$ particle emissions [61]. SOx emissions consistently decrease because all the scenarios look for an alternate to coal as an energy source. NOx emissions are always higher than 2010 for all of the RCP scenarios. OC emission goes down by 2050 for RCP4.5 and RCP8.5, but increases a little for RCP6.0. OC emission can be tied to that particular scenario's stress on using biomass burning as a source of fuel.
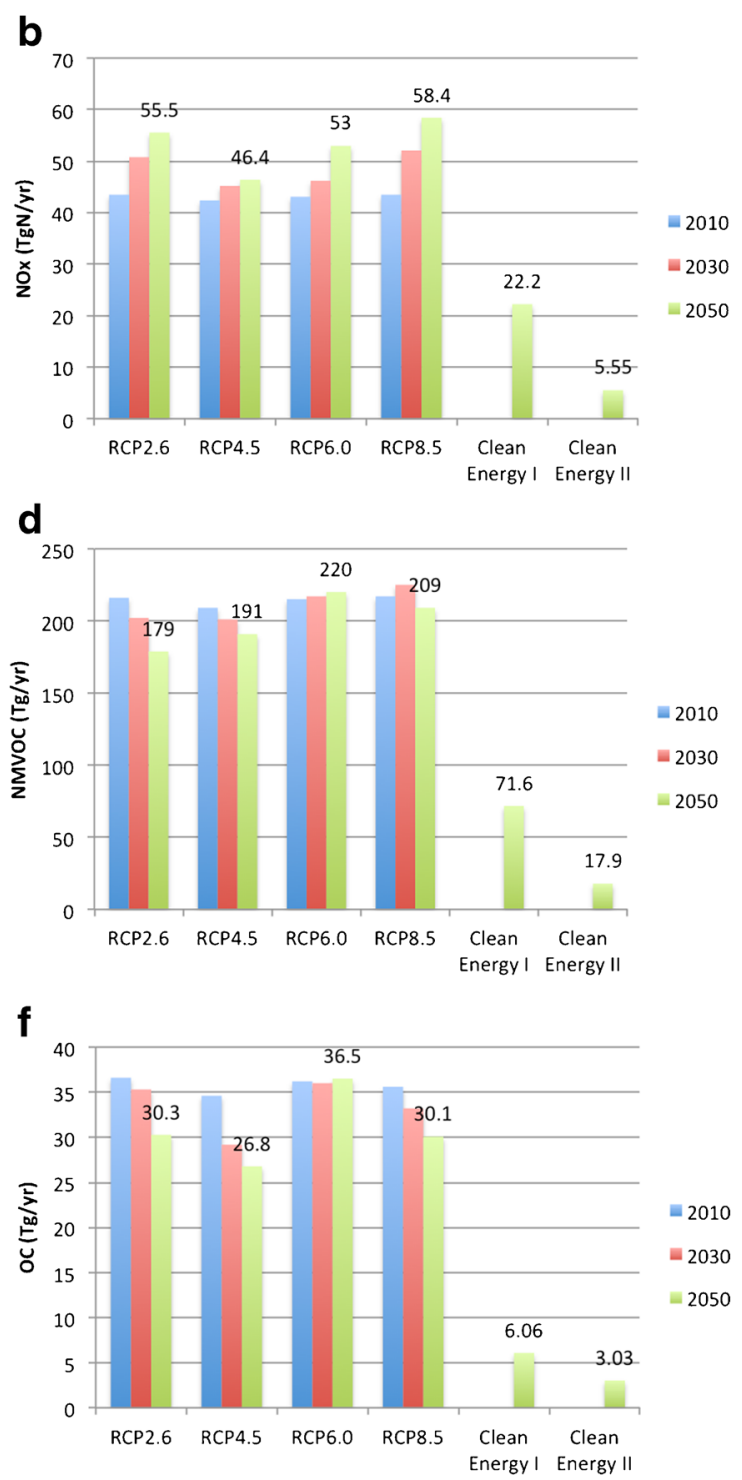

that still depends heavily on use of biofuels and Clean Energy Scenario II in which dependence on biofuel is much lower for 2050 only. The numbers on the green bars indicate emission in 2050 for the different scenarios

\section{A Clean Energy Future}

The most likely means that can be implemented to improve air quality while also reducing effects on future climate are increased use of renewable energy technologies, more efficient energy utilization, alternative energies for transportation, and increased energy storage technologies. In this section, we consider a clean energy future.

Although transitioning our energy system to cleaner fuels and/or changing to complete renewable sources of energy may seem daunting, the potential benefits to human health and lives are large. A number of studies have begun to examine alternative energy futures. A $100 \%$ renewable energy system is technically possible and may even be economically 
beneficial compared to the present situation [62]. A change to cleaner sources of energy would greatly reduce the emissions of short-lived species affecting ozone and PM2.5, and thus reduce concerns about air pollution, while also reducing emissions of the long-lived species having the largest effects on climate. We start the discussion by examining alternative renewable energy technologies for the transportation and electricity production sectors.

\section{Transportation Systems}

The majority of today's vehicles operate on gasoline or diesel, although some use liquefied petroleum or compressed natural gas. A number of studies have shown transportation to be a major source of ozone and PM2.5 precursor emissions. For example, a study in the San Francisco area showed that trucks account for 56 and $26 \%$ of BC and OA emissions, respectively [63]. Vehicular exhaust contributed about 17.1, 40, and about $17-24 \%$ of primary PM2.5 pollution in Beijing [64], in six cities in Brazil [65], and in Milan [66], respectively.

To control emissions from vehicles, one of the control measures that can be applied is use of alternative fuels like biodiesel, hydrogen, natural gas, ethanol, propane, and electricity. Addition of biofuel additives to gasoline and diesel vehicles is a common practice to reduce tailpipe emissions. The addition of biofuels to gasoline and diesel engines reduces $\mathrm{CO}_{2}, \mathrm{CO}$, and VOC emissions (because of the presence of more oxygenated fuels), but does not show any appreciable change in $\mathrm{NO} x$ emissions [67-70].

Natural gas vehicles have been shown to improve air quality by reducing particulate emissions and photochemical smog. Introducing compressed natural gas $(\mathrm{CNG})$ vehicles to the fleet reduces emissions of air pollutants overall, but increases hydrocarbons (specially methane due to leakage) [71-77]. Although biofuels additives and CNG engines may reduce tailpipe emission to a certain extent, the overall energy production is still fossil fuel based, and their use does not eliminate emissions of all key pollutants.

Another method is to shift to hybrid and/or electric and/or hydrogen fueled vehicles. Electric vehicles use electrical energy stored in rechargeable batteries and other energy storage devices, hybrid vehicles combine internal combustion engines with electric motors, and hydrogen-fueled vehicles use either hydrogen fuel cells or hydrogen in internal combustion engines as an energy source. Electrification of the vehicles will address three important environmental issues: (a) reduction of GHG emissions; (b) reduction of tail pipe emissions affecting air quality; and (c) reduction of gasoline consumption, which will reduce air pollutant emissions [78].

Plug in hybrid vehicles uses electricity from the grid to power a portion of the vehicle use, but there is still use of petroleum-based fuels. If charged with other than fossil fuel intense electricity sources, hybrid vehicles can reduce gasoline consumption, resulting in reduced tail pipe emissions [78-80]. The use of plug in hybrid vehicles also reduces NOx emissions and resulting $\mathrm{O}_{3}$ production [81].

Electric vehicles have the potential to transform the effects of vehicles on the environment, especially if the electricity comes from non-fossil fuel sources [82]. Since electric vehicles do not depend on petroleum-based fuels at all, there are no tail pipe emissions. The global-warming potential (GWP) of electric vehicles is much lower than gasoline or diesel vehicles, even if the electricity does come from fossil fuel sources [82-87]. At present a conventional vehicle emits $100-150 \mathrm{~g}$ of $\mathrm{CO}_{2} / \mathrm{km}$ whereas a hybrid vehicle achieves about $90 \mathrm{~g}$ of $\mathrm{CO}_{2} / \mathrm{km}$. Electric vehicles have the potential to reduce this to about $50 \mathrm{~g} \mathrm{CO}_{2} / \mathrm{km}$ vehicle travelled [88••], when using fossil fuels as their power source, and it goes to zero when using power from alternate energy.

Another potential alternate fuel is based on the use of hydrogen $\left(\mathrm{H}_{2}\right)$. Hydrogen itself is not a primary energy source but it can be produced in fuel cells through catalysis or burned in internal combustion engines to supply electricity to the cars. Hydrogen gas can be extracted in various ways, from many conventional sources like coal and biomass, or from clean sources like water, wind, or solar power. Since it can be extracted from both renewable and non-renewable sources, it would be easy to incorporate it into an existing energy structure [89]. $\mathrm{H}_{2}$ fuel cells emit only water vapor, thus eliminating $\mathrm{CO}, \mathrm{NO} x$, and VOC emissions from the tailpipe. Both $\mathrm{H}_{2}$ fuel cells and $\mathrm{H}_{2}$ combustion engines could greatly decrease the $\mathrm{O}_{3}, \mathrm{CO}$, NOx, and soot atmospheric burdens [90]. Vehicles powered by hydrogen extracted using wind energy for the chemical conversion could save 2300 to 4000 lives/year and $\$ 32$ billion to $\$ 180$ billion relative to even hybrid vehicles and could reduce asthma by 1 to 3 million cases/year relative to conventional vehicles in the USA due to improvement in air quality. [91].

All alternate technologies discussed above for vehicles significantly reduce the tail pipe emissions compared to the conventional vehicles. A key factor though is that these vehicles need a "electric supply" to charge the batteries or to provide hydrogen in the combustion engines; if the electricity production still depends on conventional fossil fuel sources of energy then the net pollution will still be high.

\section{Electricity Production and Other Energy Use}

As mentioned earlier, electricity production and other energy use (e.g., use of fossil fuels by industry) currently account for very high pollutant emissions in the USA and throughout the world. Alternate sources of energy like nuclear power, and renewable power sources like hydroelectricity, wind, solar, and geothermal, and even to some extent biomass burning, have the potential to provide energy with greatly reduced pollutant emissions, thus improving air quality and also 
mitigating GHG production. It has been estimated that to keep further changes in climate below $2{ }^{\circ} \mathrm{C}$ throughout the twenty-first century, the cumulative carbon emission between 2011 and 2050 have to be limited to around $1100 \mathrm{Gt} \mathrm{CO}_{2}$ [92]. But to meet this level globally, a third of oil reserves, half of gas reserves and over $80 \%$ of current coal reserves would need to remain unused for energy production from 2010 to 2050 [93]. All conventional sources of energy like coal, oil, and natural gas are all non-renewable and unevenly distributed in the earth with the Middle East holding the maximum oil reserves, Russia holding the maximum natural gas reserves, and the USA holding the maximum coal reserves. How long these reserves last will depend on the demand we put on them. In absence of any mitigation policy, the world's energy use of fossil fuels would rise by over one third by 2035 with demand of coal rising by $21 \%$ and natural gas by $51 \%$. The power sector would increase from $\sim 20 \%$ today to $31 \%$ in 2035 . These analyses suggest energy demand in China would likely account for the largest share of the projected growth in global energy use demand, rising by $60 \%$ in 2035, followed by India and the Middle East [33].

Table 2 gives the data for the changing demand of different energy sources in the whole world, in the OECD90 countries, and Asia till 2050 for three different SRES emission scenarios, B1, A1B, and A1FI (adapted from Nakicenovic et al. [94]). Before going into the description of the trend in the data some of the terms used in association with the table are clarified first. The Organisation for Economic Co-operation and Development
(OECD) is comprised of the higher developed countries; OECD90 consists of 90 countries from Western Europe, Northern America, and higher developed Pacific nations such as Australia, New Zealand, and Japan. Asian countries like China and India are going through extensive economic growth and an unprecedented growth of energy and population is seen in this region. Regarding the IPCC SRES scenarios, we would expect the highest transition to alternate energy technologies in the B1 scenario, and the least in the A1FI scenario. Until at least mid century, total energy demand in Asia should increase at a higher rate than that in the OECD countries. Even in the most conservative scenario B1, energy from fossil fuels (coal and oil) keeps on increasing to 2050 for Asia. The OECD countries reduce dependence on fossil fuel by 2050 in the B1 and A1B scenarios, but in the fossil fuel intensive scenario A1FI, the consumption increases even for OECD countries. The B1 scenario does not consider nuclear power as a viable alternate energy. But use of biomass burning increases in both Asia and the OECD countries for all the scenarios, but we do not see a similar trend in renewable energy, and actually we see a reduction in use of renewable energy in Asia in case of B1 scenario. Even in the A1FI scenario, the use of alternative energy sources increase, but this is mostly because of the high-energy demand projected by this scenario. From Fig. 3, while pollutant emissions are reduced in the lower emission scenarios, air quality would still remain a serious issue over the coming decades. Only by a dramatic switch to alternatives can we greatly reduce air quality concerns.
Table 2 Changing energy usage in the world, OECD countries and Asia from 2010 to 2050 under three of the SRES emission scenarios, B1, A1B, and A1FI

\begin{tabular}{|c|c|c|c|c|c|c|c|c|c|c|}
\hline & & \multicolumn{3}{|l|}{ B1 } & \multicolumn{3}{|l|}{ A1B } & \multicolumn{3}{|l|}{ A1FI } \\
\hline & & World & OECD & Asia & World & OECD & Asia & World & OECD & Asia \\
\hline \multirow[t]{3}{*}{ Coal (EJ) } & 2010 & 120 & 46 & 51 & 134 & 41 & 64 & 150 & 48 & 73 \\
\hline & 2030 & 163 & 36 & 67 & 179 & 30 & 108 & 299 & 51 & 165 \\
\hline & 2050 & 167 & 24 & 64 & 186 & 28 & 104 & 475 & 82 & 251 \\
\hline \multirow[t]{3}{*}{ Oil (EJ) } & 2010 & 176 & 74 & 39 & 209 & 92 & 45 & 150 & 79 & 30 \\
\hline & 2030 & 230 & 64 & 63 & 239 & 78 & 68 & 165 & 71 & 48 \\
\hline & 2050 & 228 & 39 & 56 & 214 & 54 & 51 & 283 & 70 & 97 \\
\hline \multirow[t]{3}{*}{ Nuclear (EJ) } & 2010 & - & - & - & 16 & 10 & 2 & 35 & 14 & 9 \\
\hline & 2030 & - & - & - & 53 & 23 & 15 & 79 & 17 & 33 \\
\hline & 2050 & - & - & - & 123 & 24 & 45 & 137 & 18 & 67 \\
\hline \multirow[t]{3}{*}{ Biomass (EJ) } & 2010 & 11 & 5 & 3 & 38 & 0 & 19 & 12 & 4 & 5 \\
\hline & 2030 & 54 & 14 & 23 & 85 & 9 & 19 & 28 & 5 & 15 \\
\hline & 2050 & 95 & 21 & 40 & 193 & 29 & 46 & 52 & 9 & 26 \\
\hline \multirow[t]{3}{*}{ Renewable (EJ) } & 2010 & 71 & 10 & 32 & 15 & 8 & 2 & 27 & 10 & 5 \\
\hline & 2030 & 61 & 10 & 23 & 40 & 16 & 10 & 42 & 10 & 11 \\
\hline & 2050 & 46 & 10 & 13 & 167 & 35 & 58 & 86 & 14 & 33 \\
\hline
\end{tabular}

The energy usage is given in terms of EJ (1EJ (exajoule) $=10^{18} \mathrm{~J}$ ) (adapted from Nakicenovic et al. [94]) 


\section{A Clean Energy Scenario}

Very few complete scenarios have been developed for an extensive switch to clean energy by 2050 . This is not because it could not be done, but there needs to be a strong willpower to do so. Also, new technology development, like battery storage systems, will likely be key to that transition. Most of the studies that we found on use of clean energy from around the world were restricted to relatively small European countries [62, 95-97]. The common feature of all these transformations was looking at high share of biomass, wind power, and solar power. Also, emphasis was given to new energy storage technologies, and the use of electric vehicles and heat pumps (to increase efficient heating and cooling in buildings). The studies showed that with these assumptions, electricity generation by renewable sources would increase in those countries, while operational cost decrease and $\mathrm{CO}_{2}$ emissions are eliminated.

Towards examining a clean energy future, we have considered three existing idealized scenarios for shifting to clean energy, two of which are based on an energy shift throughout the world and one based on the USA. [33, 98, 99]. The study for the USA [98] assumed $80 \%$ penetration of renewable energy by 2050 using technologies that are only currently available commercially. A strongly growing energy demand but much more energy efficient future in the world by 2035 is considered in scenarios developed by the World Energy Outlook 2012 [33]. A study by World Wildlife Fund for Nature (WWF) [99] looked into a $100 \%$ renewable energy world by 2050 (see Fig. 4). The working principles of all these scenarios were to primarily supply electricity through renewable energy sources while also increasing energy efficiency. Simple measures like insulating building, recycling materials, use of energy efficient materials in industries, and shifting to more efficient forms of transportation can reduce total energy demand by 2050. Bioenergy (liquid biofuels and solid biomass) are likely to be important where other renewable energy sources are not viable,

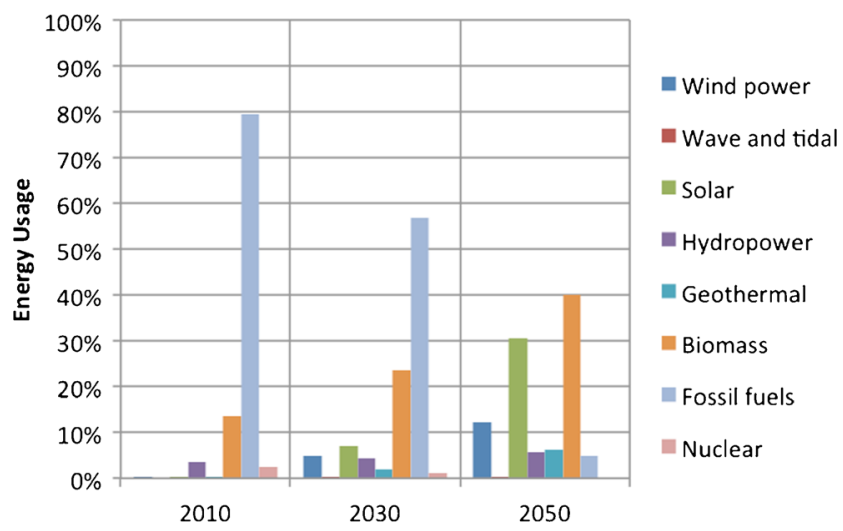

Fig. 4 Global energy provided by different sources from 2000 to 2050 for a renewable energy future (adapted from the WWF study [99]) especially in providing fuels for airplanes and ships, and in industrial processes that require high temperatures. Compared to current fuels, the use of biofuels could still result in significant emissions of NOx and VOCs, but there would likely be a significant reduction in PM2.5 precursor emissions.

Figure 4 shows the change in global energy usage by sources from 2000 to 2050 for a clean energy future based on the WWF study [99]. Energy requirement for transportation and residential uses is completely provided by alternate sources of energy. Fossil fuels are assumed to be needed for some industrial processes, particularly for their mechanical properties and not to provide energy. This scenario reduces fossil fuel usage by $95 \%$ and clean renewable sources like wind, solar, hydropower, and geothermal energy sources increase by $12,31,6$, and $6 \%$, respectively, by 2050 . Bioenergy is assumed to provide $40 \%$ of the total energy by 2050 . Implementation of these large-scale uses of alternatives will, of course, require careful planning and international cooperation. This is just one of many possible scenarios for achieving a clean energy future.

The last two sets of columns for the pollutants considered in Fig. 3 show a range of emissions for two scenarios of an idealized clean energy world. In clean energy scenario 1 , we follow the WWF scenario and assume fossil fuel use has been brought down to $5 \%$ and current fossil fuel use has been replaced by other cleaner energy sources. Therefore, emission of $\mathrm{CO}_{2}$ can also be brought down to $95 \%$ and $\mathrm{SO}_{2}$ emission can also be reduced by $95 \%$ (since its major source is fossil fuel combustion). The WWF scenario assumes that biofuels will become about $40 \%$ of the total energy production by 2050. Given this, NOx and VOC emissions should decrease relative to today in roughly proportion to the amount of use of biofuels, while $\mathrm{BC}$ and $\mathrm{OC}$ emissions are likely to be much lower, perhaps $50 \%$ of that proportion. Clean energy scenario 2 considers a world with even smaller emissions. The development of battery storage technologies, leading to electric vehicles along with much more extensive use of solar and wind power could make such an idealized clean energy world possible. If all energy production sources were entirely renewables without biofuels, and transportation systems, except for aviation (most emissions occur in the upper troposphere) and ships, were assumed to be run on electrical battery systems, then human-related emissions of NOx and VOCs can be assumed to drop by at least $90 \%$ of current emissions even when the growth in energy demand is included for 2050. BC and OC emissions are also assumed to be reduced by $90 \%$ in this scenario. Although these scenarios are hypothetical, Fig. 3 shows that a cleaner energy world would greatly reduce emissions of air pollutants, resulting in greatly reduced concerns about air quality and the resulting effects on human health. 


\section{Conclusions}

Increasing population and economic development throughout the world could continue to exert a high demand on the conventional sources of energy, leading to higher pollutant emission which will directly affect both air quality and climate change in adverse ways. Europe, North America, Japan, and the other OECD countries already have widespread development of renewable energy technologies. Developing countries like China, India, Kenya, Argentina, Costa Rica, Brazil, and others also have large resource capability and market for renewable energy.

In March 2015, Costa Rica ran for more than 75 days with $100 \%$ renewable energy using mostly hydro and wind power [100]. In rural areas in most developing countries, there is no electricity grid. In these situations, off-grid renewable technologies like solar photovoltaic cells or micro-hydroelectric system can provide cost-effective and sustainable alternative to diesel generators, kerosene lamp, or biomass burning as source of energy. This can provide electricity in homes and can also provide electricity to run schools, small businesses, and health clinics, thus increasing literacy, improving living conditions, and reducing poverty [101]. End users should also be made aware of the environmental benefits of using cleaner and newer technologies, for example using electric vehicles instead of gasoline/diesel run vehicles or constructing green buildings. This will ensure that the change from conventional energy to alternate energy sources does not meet with a high resistance from the end users. Incentives may be needed. Renewable energy gives a country energy security by providing access to clean and natural sources of energy at cheap price. To enhance the market reach of these technologies, there might also be a need to subsidize the cost of alternate energy services to make them affordable to major part of the population.

A country's physical border does not restrict impact of degrading air quality or climate change issues. International collaboration can help in controlling impact of long-range transport or intercontinental transport of air pollutants. Sharing research and newer technologies pertaining to renewable sources can help countries without the immediate means to do so in implementing these without taking a very high setback in their industrial or economic developments. IPCC which is aimed at understanding climate change and its impact and not directly related to policy developments, also include analyses of the effects of climate change on air quality (IPCC Working group II: Impacts, Adaptation, and Vulnerability) and their assessment is extremely relevant to the discussion in this paper. Such assessments provide useful guidelines for policymakers as to the importance of the issues associated with climate change. They also provide useful summaries of state of the science to help guide further research.
Greater emphasis should be given to research on clean energy like wind, solar, geothermal, and hydroelectricity. Research on new technologies like development of battery storage and incorporating electricity developed from the alternate sources in the current electricity grid system is also very important. If the renewable energy technologies take over conventional energy sources, a life cycle assessment of the newer technologies will also be very pertinent. For example, if vehicles shift from using gasoline/diesel to electric batteries from electricity generated from renewable sources, the tail pipe emission becomes almost zero but there can be newer emissions from the battery manufacturing facilities [80]. Also, as the vehicles shift to the newer technologies, older vehicles have to be scraped and similar situation will arise for all the sectors changing from conventional sources to renewable sources. Extensive research should also go into handling the waste produced so that more pollutant and GHGs are not emitted from handling the waste. Air quality research is also needed. The processes affecting local and regional ozone production are reasonably well understood, but there remain some questions about the complete chemistry of some of the hydrocarbons. Much more uncertain are the processes affecting the microphysics and chemistry in the life cycle of many of the particles. More emphasis on research in this direction is needed.

A shift from conventional energy sources that rely heavily on fossil fuel combustion, and from gasoline and diesel in vehicles, to renewable sources would greatly improve air quality and save a lot of lives. At the same time, such a shift would greatly reduce the concerns about future climate change. The study shows that such a world is possible - it is really our choice. Do we emphasize the push for the technology development required to get there or do we continue to heavily depend on fossil fuels and face the resulting effects on climate and air quality?

Conflict of Interest Dr. Wuebbles and Ms. Sanyal have no conflicts of interest.

\section{References}

Papers of particular interest, published recently, have been highlighted as:

•. Of major importance

1.• International Energy Agency Technical Report. Key world energy statistics, 2014. Website:http://www.iea.org/publications/ freepublications/publication/KeyWorld2014.pdf; 2014. Accessed 23 April 2015. Paper provides comprehensive data on energy uses and supply, transformation and consumption of all major energy sources in different parts of the world. 
2. Harrison RM, Kitto AMN. Estimation of the rate constant for the reaction of acid sulphate aerosol with $\mathrm{NH} 3$ gas from atmospheric measurements. J Atmos Chem. 1992;15(2):133-43.

3. Timmer B, Olthuis W, Van Den Berg A. Ammonia sensors and their applications-a review. Sensors Actuators B Chem. 2005;107(2):666-77.

4. Burton RM, Suh HH, Koutrakis P. Spatial variation in particulate concentrations within metropolitan Philadelphia. Environ Sci Technol. 1996;30(2):400-7.

5. Delmas R, Serça D, Jambert C. Global inventory of NOx sources. Nutr Cycl Agroecosyst. 1997;48(1-2):51-60.

6. Harrison RM, Yin J. Particulate matter in the atmosphere: which particle properties are important for its effects on health? Sci Total Environ. 2000;249(1):85-101.

7. Hildemann LM, Markowski GR, Cass GR. Chemical composition of emissions from urban sources of fine organic aerosol. Environ Sci Technol. 1991;25(4):744-59.

8. Rogge WF, Hildemann LM, Mazurek MA, Cass GR, Simoneit BR. Sources of fine organic aerosol. 1. Charbroilers and meat cooking operations. Environ Sci Technol. 1991;25(6):1112-25.

9. Rogge WF, Hildemann LM, Mazurek MA, Cass GR, Simoneit BR. Sources of fine organic aerosol. 2. Noncatalyst and catalystequipped automobiles and heavy-duty diesel trucks. Environ Sci Technol. 1993;27(4):636-51.

10. Hallquist M, Wenger JC, Baltensperger U, Rudich Y, Simpson D, Claeys M, et al. The formation, properties and impact of secondary organic aerosol: current and emerging issues. Atmos Chem Phys. 2009;9(14):5155-236.

11. Russell LM. Aerosol organic-mass-to-organic-carbon ratio measurements. Environ Sci Technol. 2003;37(13):2982-7.

12. Bond TC, Doherty SJ, Fahey DW, Forster PM, Berntsen T, DeAngelo BJ, et al. Bounding the role of black carbon in the climate system: a scientific assessment. J Geophys Res Atmos. 2013;118(11):5380-552.

13. EPA, U.S. Air quality criteria for particulate matter (final report, Oct 2004). U.S. Environmental Protection Agency, Washington, DC. 2004. EPA 600/P-99/002aF-bF.

14. Schwartz J, Laden F, Zanobetti A. The concentration-response relation between PM (2.5) and daily deaths. Environ Health Perspect. 2002;110(10):1025.

15. Anderson HR. Air pollution and mortality: a history. Atmos Environ. 2009;43(1):142-52.

16. Hyslop NP. Impaired visibility: the air pollution people see. Atmos Environ. 2009;43(1):182-95.

17. IPCC. Climate change 2007: the physical science basis. Contribution of Working Group I to the Fourth Assessment Report (AR4) of the Intergovernmental Panel on Climate Change. 2007. 996 pp.

18. Caiazzo F, Ashok A, Waitz IA, Yim SH, Barrett SR. Air pollution and early deaths in the United States. Part I: quantifying the impact of major sectors in 2005. Atmos Environ. 2013;79:198-208.

19.• International Energy Agency Technical Report. Key world energy statistics. 2012. Website: http://www.iea.org/publications/ freepublications/publication/IEA Annual Report publicversion. pdf. Accessed 23 April 2015. Paper provides comprehensive data on energy uses and supply, transformation and consumption of all major energy sources in different parts of the world.

20. Panwar NL, Kaushik SC, Kothari S. Role of renewable energy sources in environmental protection: a review. Renew Sust Energ Rev. 2011;15(3):1513-24.

21.• IPCC. Summary for policymakers. In: Edenhofer O, PichsMadruga R, Sokona Y, Farahani E, Kadner S, Seyboth K, editors. Climate change 2014, mitigation of climate change. Contribution of Working Group III to the Fifth Assessment Report of the Intergovernmental Panel on Climate Change. Cambridge University Press. 2014. This report summarises the policy recommendations and findings from the the Working Group III assessment related to mitigation and adaptation in response to climate change.

22.• The Regulatory Assistance Project. Quantifying the air quality impacts of energy efficiency policies and programs. 2013. Website: www.raponline.org/document/download/id/6680. Accessed 23 April 2015. This report provides air quality regulators to data sources and methods for quantifying the air quality impacts of energy efficiency policies and programs.

23. National Research Council. Advancing the science of climate change. Washington, DC: The National Academies Press; 2010. Website: http://www.nap.edu/openbook.php?record_id=12782. Accessed 23 April 2015.

24. Energy and Air Pollution. 2012. Website: http://www.kean.edu/ csmart/Observing/18.\%20Energy\%20and\%20air\%20pollution. pdf. Accessed 23 April 2015.

25. National Research Council. Hidden costs of energy: unpriced consequences of energy production and use. Washington, DC: The National Academies Press; 2010. Website: http://www.nap.edu/ openbook.php?record_id=12794. Accessed 23 April 2015.

26. Clarke L, Edmonds J, Jacoby H, Pitcher H, Reilly J, Richels R. Scenarios of greenhouse gas emissions and atmospheric concentrations. Sub-report 2.1A of Synthesis and Assessment Product 2.1 by the U.S. Climate Change Science Program and the Subcommittee on Global Change Research (2007). Washington, DC.: Department of Energy, Office of Biological \& Environmental Research. 2007. $154 \mathrm{pp}$.

27. Smith SJ, Wigley TML. Multi-gas forcing stabilization with Minicam. Energy J. 2006;6:373-91.

28. Wise M, Calvin K, Thomson A, Clarke L, Bond-Lamberty B, Sands R, et al. Implications of limiting $\mathrm{CO} 2$ concentrations for land use and energy. Science. 2009;324(5931):1183-6.

29. Smith SJ, Pitcher H, Wigley TM. Global and regional anthropogenic sulfur dioxide emissions. Glob Planet Chang. 2001;29(1):99-119.

30. Bond TC, Bhardwaj E, Dong R, Jogani R, Jung S, Roden C, et al. Historical emissions of black and organic carbon aerosol from energy-related combustion, 1850-2000. Glob Biogeochem Cycles. 2007;21(2), GB2018.

31. Lamarque JF, Bond TC, Eyring V, Granier C, Heil A, Klimont Z, et al. Historical (1850-2000) gridded anthropogenic and biomass burning emissions of reactive gases and aerosols: methodology and application. Atmos Chem Phys. 2010;10(15):7017-39.

32. EPA, U.S. Our nation's air - status and trends through 2010. Washington, DC: U.S. Environmental Protection Agency; 2010. EPA-454/R-12-001.

33. International Energy Agency Technical Report. World energy outlook. 2012. Website: http://www.worldenergyoutlook.org/ publications/weo-2012/. Accessed 23 April 2015.

34. Melillo JM, Richmond TC, Yohe GW. Climate Change Impacts in the United States: The Third National Climate Assessment. U.S. Global Change Research Program. 2014; 841 pp. doi:10.7930/ J0Z31WJ2.

35. DOT Center for Climate Change and Environmental Forecasting, Federal Research Partnership Workshop. The Potential Impacts of Climate Change on Transportation. 2002. Website: http://climate. dot.gov/documents/workshop1002/workshop.pdf. Accessed 23 April 2015.

36. Wuebbles DJ, Hayhoe K. Climate change projections for the United States Midwest. Mitig Adapt Strateg Glob Chang. 2004;9(4):335-63.

37. Frumhoff PC, McCarthy JJ, Melillo JM, Moser SC,Wuebbles DJ. Confronting climate change in the US Northeast. A report of the northeast climate impacts assessment. Cambridge: Union of Concerned Scientists; 2007.

38. Holloway T, Spak SN, Barker D, Bretl M, Moberg C, Hayhoe K, et al. Change in ozone air pollution over Chicago associated with 
global climate change. J Geophys Res Atmos. 2008;113, D22306. doi:10.1029/2007JD009775.

39. Jacob DJ, Winner DA. Effect of climate change on air quality. Atmos Environ. 2009;43(1):51-63.

40. Ravishankara AR, Dawson JP, Winner DA. New directions: adapting air quality management to climate change: a must for planning. Atmos Environ. 2012;50:387-9.

41. Anenberg SC, Schwartz J, Vignati E, Emberson L, Muller NZ, West JJ, et al. Global air quality and health co-benefits of mitigating near-term climate change through methane and black carbon emission controls. Environ Health Perspect. 2012;120(6):831-9.

42.• Schmale J, Shindell D, von Schneidemesser E, Chabay I, Lawrence M. Air pollution: clean up our skies. Nature. 2014;515:335-7. A recent study showing the neccessity of controlling greenhouse gas emission and improving air quality together.

43. IPCC. IPCC special report on emissions scenarios. Prepared by Working Group III of the Intergovernmental Panel on Climate Change. Cambridge: Cambridge University Press. 2000.

44. Moss RH, Edmonds JA, Hibbard KA, Manning MR, Rose SK, Van Vuuren DP, et al. The next generation of scenarios for climate change research and assessment. Nature. 2010;463(7282):747-56.

45. Lin JT, Wuebbles DJ, Liang XZ. Effects of intercontinental transport on surface ozone over the United States: present and future assessment with a global model. Geophys Res Lett. 2008;35(2), L02805.

46. Lin JT, Patten KO, Hayhoe K, Liang XZ, Wuebbles DJ. Effects of future climate and biogenic emissions changes on surface ozone over the United States and China. J Appl Meteorol Climatol. 2008;47(7):1888-909.

47. Weaver CP, Cooter E, Gilliam R, Gilliland A, Grambsch A, Grano $\mathrm{D}$, et al. A preliminary synthesis of modeled climate change impacts on US regional ozone concentrations. Bull Am Meteorol Soc. 2009;90(12):1843-63.

48. Wu S, Duncan BN, Jacob DJ, Fiore AM, Wild O. Chemical nonlinearities in relating intercontinental ozone pollution to anthropogenic emissions. Geophys Res Lett. 2009;36(5), L05806.

49. Wu S, Mickley LJ, Jacob DJ, Rind D, Streets DG. Effects of 2000-2050 changes in climate and emissions on global tropospheric ozone and the policy-relevant background surface ozone in the United States. J Geophys Res. 2008;113, D18312. doi:10. 1029/2007JD009639.

50. Wild O, Fiore AM, Shindell DT, Doherty RM, Collins WJ, Dentener FJ, et al. Modelling future changes in surface ozone: a parameterized approach. Atmos Chem Phys. 2012;12(4):2037-54.

51. Tao Z, Williams A, Huang HC, Caughey M, Liang XZ. Sensitivity of US surface ozone to future emissions and climate changes. Geophys Res Lett. 2007;34(8), L08811.

52. Gao Y, Fu JS, Drake JB, Lamarque JF, Liu Y. The impact of emission and climate change on ozone in the United States under representative concentration pathways (RCPs). Atmos Chem Phys. 2013;13(18):9607-21.

53. Penrod A, Zhang Y, Wang K, Wu SY, Leung LR. Impacts of future climate and emission changes on US air quality. Atmos Environ. 2014;89:533-47.

54. Tagaris E, Manomaiphiboon K, Liao KJ, Leung LR, Woo JH, He $\mathrm{S}$, et al. Impacts of global climate change and emissions on regional ozone and fine particulate matter concentrations over the United States. J Geophys Res Atmos. 2007;112, D14312.

55. Lam YF, Fu JS, Wu S, Mickley LJ. Impacts of future climate change and effects of biogenic emissions on surface ozone and particulate matter concentrations in the United States. Atmos Chem Phys. 2011;11(10):4789-806.

56. Doherty RM, Wild O, Shindell DT, Zeng G, MacKenzie IA, Collins WJ, et al. Impacts of climate change on surface ozone and intercontinental ozone pollution: a multi-model study. J Geophys Res Atmos. 2013;118(9):3744-63.

57. Lei H, Wuebbles DJ, Liang XZ. Projected risk of high ozone episodes in 2050. Atmos Environ. 2012;59:567-77.

58. Lei H, Wuebbles DJ, Liang XZ, Olsen S. Domestic versus international contributions on 2050 ozone air quality: how much is convertible by regional control? Atmos Environ. 2013;68:315-25.

59. Huang HC, Lin J, Tao Z, Choi H, Patten K, Kunkel K, et al. Impacts of long-range transport of global pollutants and precursor gases on US air quality under future climatic conditions. J Geophys Res Atmos. 2008;113, D19307.

60. Lin JT, Youn D, Liang XZ, Wuebbles DJ. Global model simulation of summertime US ozone diurnal cycle and its sensitivity to PBL mixing, spatial resolution, and emissions. Atmos Environ. 2008;42(36):8470-83.

61. Cubasch U, Wuebbles D, Chen D, Facchini MC, Frame D, Mahowald $\mathrm{N}$ et al. (2013) Introduction. In: Stocker TF, Qin D, Plattner G-K, Tignor M, Allen SK, Boschung J, editors. Climate change 2013: the physical science basis. Contribution of Working Group I to the Fifth Assessment Report of the Intergovernmental Panel on Climate Change. Cambridge University Press, Cambridge, United Kingdom and New York, NY, USA

62. Mathiesen BV, Lund H, Karlsson K. 100\% Renewable energy systems, climate mitigation and economic growth. Appl Energy. 2011;88(2):488-501.

63. Dallmann TR, Onasch TB, Kirchstetter TW, Worton DR, Fortner EC, Herndon SC, et al. Characterization of particulate matter emissions from on-road gasoline and diesel vehicles using a soot particle aerosol mass spectrometer. Atmos Chem Phys. 2014;14(14):7585-99.

64. Yu L, Wang G, Zhang R, Zhang L, Song Y, Wu B, et al. Characterization and source apportionment of PM2.5 in an urban environment in Beijing. Aerosol Air Qual Res. 2013;13(2):574 83.

65. de Fatima Andrade M, de Miranda RM, Fornaro A, Kerr A, Oyama B, de Andre PA, et al. Vehicle emissions and PM2.5 mass concentrations in six Brazilian cities. Air Qual Atmos Health. 2012;5(1):79-88.

66. Perrone MG, Larsen BR, Ferrero L, Sangiorgi G, De Gennaro G, Udisti R, et al. Sources of high PM2.5 concentrations in Milan, Northern Italy: molecular marker data and CMB modelling. Sci Total Environ. 2012;414:343-55.

67. Aslam MU, Masjuki HH, Kalam MA, Abdesselam H, Mahlia TMI, Amalina MA. An experimental investigation of $\mathrm{CNG}$ as an alternative fuel for a retrofitted gasoline vehicle. Fuel. 2006;85(5):717-24.

68. Yeh S. An empirical analysis on the adoption of alternative fuel vehicles: the case of natural gas vehicles. Energy Policy. 2007:35(11):5865-75.

69. Canakci M, Ozsezen AN, Alptekin E, Eyidogan M. Impact of alcohol-gasoline fuel blends on the exhaust emission of an SI engine. Renew Energy. 2013;52:111-7.

70. Can Ö. Combustion characteristics, performance and exhaust emissions of a diesel engine fueled with a waste cooking oil biodiesel mixture. Energy Convers Manag. 2014;87:676-86.

71. Dondero L, Goldemberg J. Environmental implications of converting light gas vehicles: the Brazilian experience. Energy Policy. 2005;33(13):1703-8.

72. Fontaras G, Martini G, Manfredi U, Marotta A, Krasenbrink A, Maffioletti F, et al. Assessment of on-road emissions of four Euro $\mathrm{V}$ diesel and CNG waste collection trucks for supporting airquality improvement initiatives in the city of Milan. Sci Total Environ. 2012;426:65-72.

73. Suthawaree J, Sikder HA, Jones CE, Kato S, Kunimi H, Kabir ANMH, et al. Influence of extensive compressed natural gas (CNG) usage on air quality. Atmos Environ. 2012;54:296-307. 
74. Massoli P, Fortner EC, Canagaratna MR, Williams LR, Zhang Q, Sun Y, et al. Pollution gradients and chemical characterization of particulate matter from vehicular traffic near major roadways: results from the 2009 Queens College Air Quality study in NYC. Aerosol Sci Technol. 2012;46(11):1201-18.

75. Park SA, Tak H. The environmental effects of the CNG bus program on metropolitan air quality in Korea. Ann Reg Sci. 2012;49(1):261-87.

76. Wadud Z, Khan T. Air quality and climate impacts due to $\mathrm{CNG}$ conversion of motor vehicles in Dhaka, Bangladesh. Environ Sci Technol. 2013;47(24):13907-16.

77. Tessum CW, Hill JD, Marshall JD. Life cycle air quality impacts of conventional and alternative light-duty transportation in the United States. Proc Natl Acad Sci. 2014;111(52):18490-5.

78. Michalek JJ, Chester M, Jaramillo P, Samaras C, Shiau CSN, Lave LB. Valuation of plug-in vehicle life-cycle air emissions and oil displacement benefits. Proc Natl Acad Sci. 2011;108(40):165548.

79. Granovskii M, Dincer I, Rosen MA. Economic and environmental comparison of conventional, hybrid, electric and hydrogen fuel cell vehicles. J Power Sources. 2006;159(2):1186-93.

80. Samaras C, Meisterling K. Life cycle assessment of greenhouse gas emissions from plug-in hybrid vehicles: implications for policy. Environ Sci Technol. 2008;42(9):3170-6.

81. Thompson TM, King CW, Allen DT, Webber ME. Air quality impacts of plug-in hybrid electric vehicles in Texas: evaluating three battery charging scenarios. Environ Res Lett. 2011;6(2): 024004.

82. Nanaki EA, Koroneos CJ. Comparative economic and environmental analysis of conventional, hybrid and electric vehicles-the case study of Greece. J Clean Prod. 2013;53:261-6.

83. Peterson SB, Whitacre JF, Apt J. Net air emissions from electric vehicles: the effect of carbon price and charging strategies. Environ Sci Technol. 2011;45(5):1792-7.

84. Brady J, O'Mahony M. Travel to work in Dublin. The potential impacts of electric vehicles on climate change and urban air quality. Transp Res Part D: Transp Environ. 2011;16(2):188-93.

85. Hawkins TR, Gausen OM, Strømman AH. Environmental impacts of hybrid and electric vehicles - a review. Int J Life Cycle Assess. 2012;17(8):997-1014.

86. Hawkins TR, Singh B, Majeau-Bettez G, Strømman AH. Comparative environmental life cycle assessment of conventional and electric vehicles. J Ind Ecol. 2013;17(1):53-64.

87. Huo H, Cai H, Zhang Q, Liu F, He K. Life-cycle assessment of greenhouse gas and air emissions of electric vehicles: a comparison between China and the US. Atmos Environ. 2015;108:107-16.
88.• International Energy Agency. Global EV yearbook Understanding the electric vehicle landscape to 2020, 2013. Website: https:// www.iea.org/publications/globalevoutlook_2013.pdf. Accessed 23 April 2015. The report outlines the importance of Electric Vehicles in increasing energy security and controlling emission of greenhouse gases and other pollutants.

89. Hoffmann P. Tomorrow's energy: hydrogen, fuel cells, and the prospects for a cleaner planet. Cambridge: MIT Press; 2012.

90. Wang D, Jia W, Olsen SC, Wuebbles DJ, Dubey MK, Rockett AA. Impact of a future H 2-based road transportation sector on the composition and chemistry of the atmosphere-part 1: tropospheric composition and air quality. Atmos Chem Phys. 2013;13(13):6117-37.

91. Jacobson MZ, Colella WG, Golden DM. Cleaning the air and improving health with hydrogen fuel-cell vehicles. Science. 2005;308(5730):1901-5.

92. Meinshausen M, Meinshausen N, Hare W, Raper SC, Frieler K, Knutti R, et al. Greenhouse-gas emission targets for limiting global warming to $2{ }^{\circ} \mathrm{C}$. Nature. $2009 ; 458(7242): 1158-62$.

93. McGlade C, Ekins P. The geographical distribution of fossil fuels unused when limiting global warming to $2{ }^{\circ} \mathrm{C}$. Nature. 2015;517(7533):187-90.

94. Groupe d'experts intergouvernemental sur l'évolution du climat. Working group 3. Special report on emissions scenarios: a special report of working group III of the Intergovernmental Panel on Climate Change. Cambridge: Cambridge University Press; 2000.

95. Ćosić B, Krajačić G, Duić N. A 100\% renewable energy system in the year 2050: the case of Macedonia. Energy. 2012;48(1):80-7.

96. Melikoglu M. Vision 2023: feasibility analysis of Turkey's renewable energy projection. Renew Energy. 2013;50:570-5.

97. Hinrichs-Rahlwes R. Renewable energy: paving the way towards sustainable energy security: lessons learnt from Germany. Renew Energy. 2013;49:10-4.

98. National Renewable Energy Laboratory. Renewable electricity, future study, executive summary. Website: http://www.nrel.gov/ docs/fy13osti/52409-ES.pdf. Accessed 23 April 2015.

99. World Wildlife Fund. The energy report, $100 \%$ renewable energy by 2050 . Website: http://assets.panda.org/downloads/the_energy_ report lowres 111110.pdf. Accessed 23 April 2015.

100. Science Alert. Costa Rica powered with $100 \%$ renewable energy for 75 straight days. Website: http://www.sciencealert.com/costarica-powered-with-100-renewable-energy-for-75-days. Accessed 02 June 2015.

101. The World Watch Institute. Energy for development: the potential role of renewable energy in meeting the millennium development goals. Website: http://www.worldwatch.org/system/files/ren21-1.pdf. Accessed 03 June 2015. 